\title{
Oral Academic Discourse Socialization of an ESL Chinese Student: Cohesive Device Use
}

\author{
Sue Wang ${ }^{1} \&$ Tammy Slater ${ }^{2}$ \\ ${ }^{1}$ School of Foreign Studies, Central University of Finance and Economics, Beijing, China \\ ${ }^{2}$ Applied Linguistics and Technology Program, Iowa State University, Ames, IA, United States. \\ Correspondence: Sue Wang, School of Foreign Studies, Central University of Finance and Economics, 39 South \\ College Road, Haidian District, Beijing, China, 100081. E-mail: suewang100@yahoo.com
}

$\begin{array}{ll}\text { Received: November 10, } 2015 & \text { Accepted: December 13, 2015 Online Published: January 31, } 2016 \\ \text { doi:10.5539/ijel.v6n1p65 } & \text { URL: http://dx.doi.org/10.5539/ijel.v6n1p65 }\end{array}$

\begin{abstract}
Framed in language socialization theory, this study examines the longitudinal cohesive device development of an ESL Chinese graduate student over time during his discourse socialization by focusing on his oral presentations through a systemic functional linguistics approach. The study found that the participant improved in his use of textual resources as he continued his discourse socialization in the academic community that he had joined. Yet the problems and challenges the participant faced during his development of cohesive devices also illustrated the complexity and non-linear characteristics of academic discourse socialization. The study contributes to language socialization research by employing a systemic functional linguistics approach as an analysis tool for longitudinal linguistic discourse development. The findings inform second language curriculum and instruction, particularly oral language instruction.
\end{abstract}

Keywords: oral academic discourse, ESL, cohesive device

\section{Introduction}

The existing English-as-a-second-language (ESL) literature indicates that Asian students, as one of the biggest international student population both in the United States (Project Atlas) and Canada (Canadian Bureau for International Education, 2015), listed academic presentation as one of the most important skills for academic success in their graduate courses (e.g., Kim, 2006). Some researchers (e.g., Ho, 2011, Kobayashi, 2005; Morita, 2000; Zappa-Hollman, 2007) have explored this dynamic and complex academic activity from a discourse socialization perspective. Their findings indicated that discourse socialization is far from a smooth, one-way process. Instead, it was a process of constant negotiation and exercise of agency. These studies provided a dynamic picture of the oral academic discourse socialization from sociocultural theoretical perspectives (Lantolf, 2000). However, few of the second language socialization studies so far have addressed specifically how the second language (L2) progressed during this discourse socialization process.

\section{Theoretical Framework and Previous Research}

This study was conducted with language socialization as its theoretical framework. Language socialization refers to the process through which novices of a society or community acquire culture through language and learn how to use the appropriate language codes in various social contexts (Schieffelin \& Ochs, 1986), and it is frequently quoted in its original terms: "socialization through language and socialization to use the language" (p. 163). Not limited to children who are learning their native language or a second language, language socialization is a lifelong process (Ochs, 1988). In recent years, language socialization has been advocated to be an alternative research paradigm for second language acquisition (SLA) (Watson-Gegeo \& Nielsen, 2003). Several L2 studies informed by the language socialization theoretical framework have been published over the past two decades (e.g., Atkinson, 2003; Duff \& Talmy, 2011; He, 2003; Kim \& Duff, 2012; Morita, 2000). Findings from these studies on academic discourse socialization have shed light on the cultural aspects of academic discourse socialization and how students were socialized into the academic community they had just joined. However, few of these studies have detailed the L2 discourse socialization process from a systemic functional perspective, an issue worthy of investigation.

Cohesive device use as an important indicator of L2 development has attracted the attention of researchers. 
According to Halliday and Hasan (1976), cohesive devices are important ways to establish cohesion in texts. It is thus quite pertinent to examine research which has focused on the issues that language learners have with cohesive device use (e.g., Hinkel, 2002; Indriani, 2012; Karahan, 2015). For instance, in examining L2 development, Hinkel (2002) compared 68 linguistic features of texts produced by L2 writers with those of native speakers in first year composition courses. She found that L2 writers used more conjunctive and fewer lexical ties in cohesive device use. L2 writing showed less lexical control, variety, and sophistication. Hinkel concluded that many L2 texts over-rely on simple phrase- and sentence-level conjunctions and exemplification. Even advanced L2 writers were still found to have these problems. Jin (2001) noted that Chinese students tended to use sentence connectives such as "because," "as," and "so" in place of "in view with the fact that," "to begin with," and "in conclusion" (Young, 1982, p. 79, quoted in Jin, 2001). He argued that the different usage of cohesive devices in writing by native speakers of English and non-native speakers of English might be related to general areas such as thought patterns, writing organization, writing style, language, and the writers' perception of cohesion. He (2002) conducted a study specifically to explore the use of "so" by Chinese students who learned English as a foreign language. Using a corpus of both native speakers and non-native speakers, the author found that Chinese students used "so" in their writing seven to ten times that of native speakers. As to the position of "so," initial "so" occurred about $22 \%$ for natives" written English in contrast to the $78 \%$ of the corpus from Chinese middle school students and $44 \%$ for Chinese English majors. The native speakers used "so" $78 \%$ of the time in embedded position, the Chinese middle school students 22\%, and the English majors, who might be advanced in their proficiency level, $56 \%$. The author also attempted to investigate reasons for the overuse and misuse of "so" in Chinese students' writing. Learners' unawareness of spoken and written style, limited exposure to English, learners' learning/performing strategy, and negative transfer of mother tongue were listed as four major reasons.

Studies above either tried to approach L2 language development from a socialization perspective without focusing on the language development, or just analyze L2 students' end product at a certain time. This study was conducted to bridge that gap, exploring the process of ESL graduate students' language development during their L2 socialization into North American academic communities, specifically focusing on the longitudinal cohesive device development in the academic discourse socialization.

\section{Method}

Data sources for this article include video transcripts of one particular participant, Haidong, who was a $\mathrm{PhD}$ student studying physics at a university in the American Midwest, and who had been in the United States for two years at the time of the study. His four presentations presented in the study were collected from an oral English proficiency test offered at the university. This test is required of all international graduate students who would assume teaching responsibilities at the university. The test could also be taken by all international graduate students as a diagnostic test so that they might decide which ESL courses to take. The test-takers were asked to introduce some specific academic terms in their academic field among other oral tasks. The term or concept could be chosen by the test-takers and prepared before the test. The particular participant presented here took the test four times: in September 2007, December, 2007, March 2008, and September 2008, an unusual case that provided an opportunity for the researcher to observe the over-time development of this particular student. The researcher received permission from the participant to retrieve these documents as part of the study. At the same time, interviews, documents such as syllabi and reflective journals, were also collected for the study.

This paper analyzes cohesive devices in the texts of the participant's oral presentations over time, with other data acquired to triangulate the findings. It attempts to describe the linguistic development inherent in the student's academic discourse socialization from a systemic functional linguistics (SFL) approach. Originally proposed by Michael Halliday (1994), the SFL approach has been employed by a number of researchers in socialization studies and has proven to be effective (e.g., Achugar \& Colombi, 2008; Byrnes, 2006; Mohan \& Beckett, 2003). Stiefvater (2008) provided a detailed elaboration on how a functional linguistics approach is in line with language socialization, both of which are in line with Vygotskyan sociocultural theories. Schleppegrell (2004) expressed a similar opinion. In her study on the language of schooling, Schleppegrell illustrated the effectiveness of SFL in her argument that many children who had not learned academic language might perform poorly for academic tasks. Schleppegrell divided the context into three variables and listed the grammatical structures that realize those variables: field, tenor, and mode. Field refers to the ideas to be conveyed. Tenor refers to the relationship between the audience and speaker or the reader and the writer. Finally mode refers to how the language is structured to serve the ideational and interpersonal purposes of the speaker.

The SFL approach was adopted in this study focused on the mode, which refers to the textual resources used in oral presentations during the participant's academic discourse socialization. Different modes require different 
ways of presenting and organizing a text. The linguistic resources that realize mode include cohesive devices, clause-combining strategies, and thematic organization (Halliday \& Hasan, 1976; Schleppegrell, 2004). Only cohesive device use is analyzed here. According to Halliday and Hasan (1976), cohesive devices as ways to establish cohesion in texts are important. There are five types of cohesion: reference, substitution, ellipsis, lexical cohesion, and conjunction. Reference is a word or a phrase that is used in the text as an interpretation of another element in the text. Halliday and Hasan (1976) classified reference as pronominals such as he, him, his, it, hers, demonstratives and definite articles such as this, those, there, the, then (time adverbial), and comparatives such as same, similar, different, other, else. Substitution refers to replacing the previous nouns or verbs or clauses with another word or phrase. It is divided into three kinds: nominal substitutes, verbal substitutes, and clausal substitutes. Substitution is the replacement of a sentence element with another word or phrase of the same meaning. Ellipsis refers to the omission of the previously mentioned words or phrases, and can be divided into nominal ellipsis, verbal ellipsis, and clausal ellipsis. Lexical cohesion refers to either a repetition of an item or synonyms, near synonyms, or superordinate or lexical collocation. Conjunction refers to the use of words and phrases to create logical relations. It includes five kinds: additive (and, nor, that is), adversative (yet, but, however, on the contrary), causal (so, then, therefore, because, in consequence), temporal (then, first, at once, soon) and discourse (well, anyway, surely). The videotapes of the participant were transcribed and the cohesive device use were identified and analyzed based on the above five types of cohesion as the analytical framework.

\section{Results}

It was found that Haidong's cohesive device use increased over time both in terms of quantity and variety. In the following four excerpts, Haidong discussed the same or similar topics: the discovery of Newton's Law/ the discovery of Newton's law of universal gravitation. The cohesive devices in the following excerpts were analyzed in categories: references, lexical cohesion, and conjunctions (or connectors interchangeably). Ellipsis and substitution are not discussed because Haidong did not use ellipsis in these presentations. Substitution appeared in his September 2008: "Newton found that this force can be a more general one." "One" here is a substitution for "this force". While this kind of cohesive device is important, the category will not be discussed in detail here because it occurred only once in the data. The following are some excerpts from the oral presentation data.

1) I think everybody's heard about that. Yeah? Before Newton, a lot of scientists has do a lot, a lot of research to summarize the motion of a ...of a object. So they tried a lot. Newton summarize their work and then Newton got his law. (September 2007)

2) So I think everyone has heard the story of Newton's the law... how he discovered the law of universal gravitation. It is that, uh, an apple fall off the tree, it just hit Newton's head so and Newton become... started to think about, so, why would the apple fall off. So, after he think about it, he get Newton's law, which is... which is published in 1687. (December 2007)

3) So first, I would like to, I would like to go back to talk about some history, about the discovery of universal gravitation so...I think that during this process, apple have play an important role to the discovery of universal gravitation... mmm. About three hundred ago, I think all of you have learned, have know that, known that, that story as the apple fell off and it hit the head of Newton and so Newton become to think about so why the apple fall off so if that the force, that ... mmm, as soon as, as soon as the force were attracting between the earth and the moon, so Newton, Newton is ...begin to think about this question so he discovered the Newton's law of universal gravitation. (March 2008)

4) And Newton found this law about 300 years ago. And before we start I'd like to talk about how Newton discovered this law. And this law is kind of upset to us. Why Newton discovered it? And...So you know that, yeah, you know that about three hundred years again, ago, Newton was in the garden and you know an apple hit upon his head and he started to think about why is the apple fall off and so he found later that it's because the gravitation the earth applies to the apple... So there was, is a force between the apple and the earth. And later, Newton found that this force can be a more general one. So he found that every subject, every subject with masses, they would attract each other by a force. So the forces that the earth applied to the apple is just, uh, an example of the universal gravitation. (September 2008) 
Table 1. Haidong's reference use comparison

\begin{tabular}{|c|c|c|c|}
\hline September 2007 & December 2007 & March 2008 & September 2008 \\
\hline $\begin{array}{l}\text { I, everyone } \\
\text { that (Newton's law) they } \\
\text { (the scientists) their (the } \\
\text { scientists) the } \\
\text { his (Newton) }\end{array}$ & $\begin{array}{l}\text { I, everyone } \\
\text { the } \\
\text { He (Newton) } \\
\text { It (the story) } \\
\text { It (apple) }\end{array}$ & $\begin{array}{l}\text { I, you } \\
\text { the } \\
\text { This (discovery) } \\
\text { it (the apple) } \\
\text { this (the question) } \\
\text { he (Newton) }\end{array}$ & $\begin{array}{l}\text { I, we, you, us } \\
\text { the } \\
\text { this, } 3 \text { times(the law of } \\
\text { universal gravitation) } \\
\text { it (the law) } \\
\text { that (the story) } \\
\text { his (Newton) } \\
\text { he ( } 2 \text { times, Newton) } \\
\text { this (force) } \\
\text { they (every subject) } \\
\text { each other (subject) }\end{array}$ \\
\hline
\end{tabular}

Table 1 shows the linguistic resources for references that Haidong used to establish cohesion in his texts. As we can see, from September 2007 to September 2008, there were many changes in terms of using reference to establish cohesive texts. In September 2007 and even in December 2007, Haidong used only very basic reference words such as "they" referring to "the scientists" and "he" for "Newton." In comparison, in September 2008, he continued the use of "he" but he added several reference words to establish and maintain a coherent flow of the text. In addition to references, lexicons can also be used as cohesive devices as shown in Table 2, Haidong's use of lexis as cohesive devices at different times:

Table 2. Haidong's lexical cohesion use comparison

\begin{tabular}{llll}
\hline September 2007 & December 2007 & March 2008 & September 2008 \\
\hline the story & history & Discover \\
Newton's law & the discovery of universal & (this) law \\
the law of universal & gravitation & The apple \\
gravitation & apple & the force \\
apple & story & the earth \\
& The force & the gravitation \\
& Newton's law of universal & every subject \\
& gravitation & The universal gravitation \\
\hline
\end{tabular}

Table 2 shows how lexical cohesion developed over time in Haidong's discourse productions. In September 2007, Haidong did not use any lexical cohesion devices. By December 2007, he had started to use words such as "the story," "Newton's Law," and "the law of universal gravitation," repeating these lexical resources to describe the concept and thus create a sense of cohesion. By his presentation in September 2008, he was able to use more lexical cohesion devices. For instance, in talking about the discovery of the law of universal gravitation, he used to word "apple" twice in December 2008, three times in March 2008, and five times in September 2008. Moreover, in September 2008, words like "the earth" and "a/the force" were also very important in describing this concept, and the repeated use of them helped to create a more cohesive text. As Haidong continued his language socialization into his new academic community, he made evident progress in his language use.

Table 3. Haidong's connector use comparison

\begin{tabular}{llll}
\hline September 2007 & December 2007 & March 2008 & September 2008 \\
\hline before & that & so & and \\
so & so & first & before \\
and & why & as & so \\
then & and & and & that, (found that...) \\
& so & why & why \\
& after & if & that, (the forces that) \\
& which & as soon as & it \\
& & that & because \\
\hline
\end{tabular}


Table 3 shows the third kind of cohesive device, the connectors (conjunctions interchangeably used) that appeared in Haidong's presentation texts. As Haidong continued his language socialization in the new academic community, he produced longer texts and used more cohesive devices both in terms of variety and quantity. Initially, Haidong used four simple connective words. Among these, "before" functioned as a preposition to indicate time, "so" was used as a summary of what was just being done, "and then" means "as a result." In comparison, it is noticeable that Haidong introduced a "which" clause in December 2007. He also began to use more kinds of connectives such as "if" and "as soon as," although not very successfully. In September 2008, Haidong still used "and" as a loose connective, particularly at the beginning, but he was also able to use "and so" and "and later" more appropriately. He used "because" and "that" clauses appropriately in his texts.

\section{Discussion}

The ability to use more cohesive device both in terms of quantity and variety is a sign that Haidong was making progress with the increasing linguistic resources at his disposal. The examination of the four presentation texts by the participant over a year reveals an interesting increase in the numbers of "and" and "so." As he continued his language socialization in this academic community, it seemed that he developed the sense that there should be some connectors between the clauses or sentences in his oral texts. The increased number of the connectors, particularly "and" and "so," might be an attempt to set some form of connection between his ideas. Of course, in some cases, "so" is used to express the ideas of "as a result, therefore," but in many cases, his use of "so" worked simply as a filler or transition to the next mini-topic unit. Another issue that the participant mentioned in the interview was that it did not occur to him about what he had produced in his academic presentations. He was quite surprised when I showed him the transcript of his presentations. The implications will be discussed in the next section.

As mentioned in the literature review section, Hinkel (2002) found ESL writers tend to have a more limited repertoire of usage when compared with native writers. Like the participants in the Hinkel study, our data showed that the participant used some logical connectors in his presentations to create a sense of cohesion. However, he was found to primarily rely on several simple connecting words for transition or cohesion such as "and" and "so." Logical connectors as basic as "and, then, next, so" are among the most frequent. The limited use of several simple connectors in the earliest sample (September 2007) might be due to the negative transfer of his mother tongue as discussed in He (2002). Haidong in fact mentioned in his interviews that he thought a lot in Chinese and then translated his ideas into English. If there were no connectors in his Chinese, he would not be inserting them in English. Even though the participant made progress, he seemed not to have a large enough linguistically appropriate repertoire to make the text more coherent. He sometimes still did not use logical connectors between topic units and showed a lack of linguistic strategies needed to interact with the audience. In spite of the absence of comparative groups, this exploration with the oral discourse seems to draw similar conclusions to what Hinkel (2001) found. That is, the participant as a presenter tended to have a very limited repertoire and thus could only use limited linguistic resources. In this situation, he used only a limited number of cohesive devices to create cohesive texts.

This study explored the discourse socialization progress of an ESL student using an SFL approach. It is clear that the participant became more competent as he continued his language socialization in the host academic community. He made progress in using textual resources to achieve his purpose. It appeared that Haidong learned to use the language more appropriately during the continued socialization into the target community. However, as argued by Ochs (1988), language socialization is a lifelong process, and the participant was still facing challenges and difficulties in terms of language use. This also seems to indicate that learning to use the language appropriately during L2 discourse socialization in a natural environment is a long and complicated process.

Making oral presentations not only involves precise vocabulary and accurate pronunciation, there are many other progress indicators that showed in his oral productions data over time. The SFL approach can break down oral presentations into meaningful units for analysis, thus providing a valuable analytical tool for oral presentation texts.

\section{Conclusion \& Implications}

Using the SFL approach, the study presented and analyzed the cohesive devices as part of the textual resources that one ESL learner produced over time. The findings revealed that although the participant made progress during his socialization process and was able to draw on developing linguistic resources to achieve those purposes (mode) he still faced many challenges and difficulties in his one-year discourse socialization into the new academic community he was trying to be part of. 
Interviews indicated that the participant was often unaware of how his linguistic productions might affect his performance in his presentations. It is therefore important to raise L2 learners' awareness of the expected linguistic productions of oral presentations to accelerate or facilitate L2 academic discourse socialization. Discourse analysis can be used as a way to increase L2 learners' awareness of their own linguistic productions. In this way, L2 learners might self-monitor their own productions and ESL students may need to be taught more specifically, particularly about the linguistic features that are more commonly used by native speakers/writers.

The findings of this study suggest that ESL students might need to conscientiously develop their use of cohesive devices to make coherent texts. They might also need to pay more attention to how the conversational style of English can appropriately be blended with the academic written style in their oral presentations. This task might be very difficult as indicated by Hinkel (2002) when talking about L2 writing. It might be equally challenging to attain advanced L2 speaking proficiency as required in oral presentations. Even though we are aware of the difficulties, it is still possible for L2 learners to acclimate to the norms of the L2 discourse community and work towards the goal of becoming advanced L2 proficient speakers, performing demanding oral tasks such as oral presentations.

In spite of the difficulties that the participant in this study reported experiencing with oral presentations, the findings indicate that he expressed very positive attitudes towards oral presentations as a way of learning. This activity required the students not only to know the words and sentences, but they also needed to develop the capacity to organize and deliver their ideas clearly using a second language. This is very challenging for all ESL students, particularly in terms of appropriate language use. For the same reason, it can work as an excellent venue for the students to learn detailed area knowledge and demonstrate their learning. In this sense, oral presentations can work as a final step in the project-based learning/instruction cycle (Beckett, 2005). Project-based learning requires the students to take the initiative in their learning, and usually participants are required to present their projects in one way or another. Oral presentations can therefore be integrated into a curriculum that embraces exploratory learning such as project-based instruction. Special attention could be directed, as Slater, Beckett, and Afderhaar (2005) suggest, to how students improve their language use during this meaningful oral activity.

\section{Acknowledgements}

This paper is supported by Young Scholar Overseas Study Program of Chinese Scholarship Council and School of Foreign Studies, Central University of Finance and Economics. I would also like to thank my supervisor Dr. Gulbahar H. Beckett, professor in English Department, Iowa State University for her valuable suggestions and generous support.

\section{References}

Achugar, M., \& Colombi, M. C. (2008). Systemic functional linguistic explorations into the longitudinal study of the advanced capacities. In L. Ortega \& H. Byrnes (Eds.), The longitudinal study of advanced capacities (pp. 36-57). New York: Psychology Press.

Atkinson, D. (2003). Language socialization and dys-socialization in a south Indian college. In R. Bayley \& S. R. Schecter (Eds.), Language socialization in bilingual and multilingual societies (pp. 147-168). Clevedon, UK: Multilingual Matters.

Beckett, G. H. (2005). Academic language and literacy socialization through project-based instruction. Journal of Asian Pacific Communication, 15, 191-206. http://dx.doi.org/10.1075/japc.15.1.12bec

Byrnes, H. (2006). Advanced language learning: the contribution of Halliday and Vygotsky. New York: Continuum.

Canadian Bureau for International Education (2015). Facts and figures. Retrieved from http://www.cbie.ca/about-ie/facts-and-figures/

Duff, P., \& Talmy, S. (2011). Second language socialization: Beyond language acquisition in SLA. In D. Atkinson (Ed.), Alternative approaches to second language acquisition (pp. 95-116). Routledge. http://dx.doi.org/10.1002/9781444342901.ch24

Halliday, M. A. K. (1994). An introduction to functional grammar (2nd ed.). London: Edward Arnold.

Halliday, M. A. K., \& Hasan, R. (1976). Cohesion in English. London: Longman.

He, A. (2002). On the discourse marker so. Language and Computers: Studies in Practical Linguistics, 36, 40-52. 
He, A. W. (2003). Novices and their speech roles in Chinese heritage language classes. In R. Bayley \& S. R. Schecter (Eds.), Language socialization in bilingual and multilingual societies (pp. 128-146). Clevedon, UK: Multilingual Matters.

Hinkel, E. (2001). Matters of cohesion in L2 academic texts. Applied Language learning, 12, 111-132.

Hinkel, E. (2002). Second language writers' texts: Linguistic and rhetorical features. Mahwah, NJ: Lawrence Erlbaum Associates.

Jin, W. (2001). A quantitative study of cohesion of Chinese graduate students' writing: variations across genres and proficiency levels. Paper presented at the symposium on second language writing at Purdue University West Lafayette, Indiana, USA. Retrieved from http://files.eric.ed.gov/fulltext/ED452726.pdf

Ho, M. (2011). Academic discourse socialization through small-group discussions. System, 39, 437-450. http://dx.doi.org/10.1016/j.system.2011.10.015

Indriani, L. (2012). The cohesive devices in monolog discussion texts. English Education Journal, 2, 119-124. Retrieved from http://journal.unnes.ac.id/sju/index.php/eej/article/download/671/654

Karahan, P. (2015). A diagnostic analysis of ELT students' use of connectives. Procedia-Social and Behavioral Sciences, 199, 325-333. http://dx.doi.org/10.1016/j.sbspro.2015.07.555

Kim, S. (2006). Academic oral communication needs of East Asian international graduate students. English for Specific Purposes, 25, 479-489. http://dx.doi.org/10.1016/j.esp.2005.10.001

Kim, J., \& Duff, P. A. (2012).The language socialization and identity negotiations of Generation 1.5 Korean-Canadian university students. TESL Canada Journal, 29, 81-102. Retrieved from http://files.eric.ed.gov/fulltext/EJ989904.pdf

Kobayashi, M. (2005). A sociocultural study of second language tasks: Activity, agency, and language socialization. Unpublished doctoral dissertation, University of British Columbia, Vancouver, British Columbia, Canada.

Lantolf, J. P. (2000). Sociocultural theory in second language learning. Oxford: Oxford University Press.

Mohan, B., \& Beckett, G. H. (2003). A functional approach to research on content-based language learning: Recasts in casual explanations. Modern Languages Journal, 87, 421-432.

Morita, N. (2000). Discourse socialization through oral classroom activities in a TESL graduate program. TESOL Quarterly, 34, 279-311.

Ochs, E. (1988). Culture and language development: Language acquisition and socialization in a Samoan village. New York: Cambridge University Press.

Project Atlas (2015). International students in the United States. Retrieved from http://www.iie.org/Services/Project-Atlas/United-States/International-Students-In-US

Schieffelin, B. B., \& Ochs, E. (1986). Language socialization across cultures. Cambridge: Cambridge University Press.

Schleppegrell, M. J. (2004). The language of schooling. New Jersey: Lawrence Erlbaum Associates, Inc.

Slater, T., Beckett, G.H, \& Aufderhaar, C. (2005). Assessing projects as second language and content learning. In G.H. Beckett \& P Chamness Miller (Eds.), Project-based second and foreign language education: Past, present, and future (pp. 241-260). Greenwich, CT: Information Age Publishing.

Stiefvater, A. (2008). Language socialization in ESL writing classes: A systemic functional analysis. Unpublished doctoral dissertation, University of Cincinnati, Cincinnati, Ohio, United States.

Watson-Gegeo, K. A., \& Nielsen, S. (2003). Language socialization in SLA. In C. Doughty \& M. H. Long (Eds.), The handbook of second language acquisition (pp. 155-177). Malden, MA: Blackwell. http://dx.doi.org/10.1002/9780470756492.ch7

Zappa-Hollman, S. (2007). Academic presentations across post-secondary contexts: The discourse socialization of non-native English speakers. The Canadian Modern Language Review, 63, 455-485. http://dx.doi.org/10.3138/cmlr.63.4.455 


\section{Copyrights}

Copyright for this article is retained by the author(s), with first publication rights granted to the journal.

This is an open-access article distributed under the terms and conditions of the Creative Commons Attribution license (http://creativecommons.org/licenses/by/3.0/). 